\title{
DEVELOPMENT OF ELEMENTS OF THE HOUSEKEEPING SERVICE QUALITY MANAGEMENT SYSTEM IN THE HOTEL FACILITIES
}

\author{
O. Kuzmin, K. Popovich, E. Voznyuk, A. Linchevska \\ National University of Food Technologies
}

\begin{tabular}{|c|c|}
\hline Key words: & ABSTRACT \\
\hline $\begin{array}{l}\text { Quality } \\
\text { Quality control system } \\
\text { Hotel industry } \\
\text { Housekeeping service }\end{array}$ & $\begin{array}{l}\text { The article describes the housekeeping service as an integral } \\
\text { part of the hotel business, which aims to meet the needs of } \\
\text { the hotel guests. The main levels of quality control of the } \\
\text { housekeeping service and the main methods of training in }\end{array}$ \\
\hline $\begin{array}{l}\text { Article history: } \\
\text { Received 17.05.2017 } \\
\text { Received in revised form } \\
07.06 .2017 \\
\text { Accepted } 24.06 .2017\end{array}$ & $\begin{array}{l}\text { this service are considered. The concept of a quality mana- } \\
\text { gement system is revealed as one of the tools for improving } \\
\text { the quality of services. The main directions of development } \\
\text { of the housekeeping service in the context of modern inno- } \\
\text { vative processes are revealed. The elements of the house- }\end{array}$ \\
\hline $\begin{array}{l}\text { Corresponding author: } \\
\text { O. Kuzmin } \\
\text { E-mail: } \\
\text { kuzmin_ovl@nuft.edu.ua }\end{array}$ & $\begin{array}{l}\text { keeping quality management system, which are necessary } \\
\text { for standardization of service work and control over their } \\
\text { quality as well as improvement of technical level and quality } \\
\text { of services of hotel and restaurant establishments, with fur- } \\
\text { ther reduction of expenses and saving of material and labor } \\
\text { resources are developed. }\end{array}$ \\
\hline
\end{tabular}

DOI: $10.24263 / 2225-2924-2017-23-4-9$

\section{РОЗРОБКА ЕЛЕМЕНТІВ СИСТЕМИ УПРАВЛІННЯ ЯКІСТЮ СЛУЖБИ НОUSЕКЕEPING У ГОТЕЛЬНОМУ ГОСПОДАРСТВІ}

\section{О.В. Кузьмін, К.В. Попович, О.В. Вознюк, А.А. Лінчевська Національний університет харчових технологій}

У статті охарактеризовано службу Hоиsekeерing як невід'ємну складову готельного господарства, основною метою якої є задоволення потреб гостей готелю. Розглянуто основні рівні контролю якості роботи служби Housekeерing та основні методи навчання в даній службі. Розкрито поняття системи управління якості як один із важелів покращення якості послуг. Розкрито основні напрямки розвитку служби Housekeерing в контексті сучасних інноваційних процесів. Розроблено елементи системи управління якістю служби Housekeерing, які необхідні для стандартизації робіт служби та контролю над їх якістю, підвищення технічного рівня та якості послуг готельно-ресторанних закладів, при подальшому скорочені витрат та економії матеріальних і трудових ресурсів. 
Ключові слова: якість, система управління якістю, готельне господарство, служба Housekeeping.

Постановка проблеми. На сьогодні однією з головних проблем готельного господарства України є розробка та впровадження системи управління якістю (СУЯ), наявність якої залишається важливим інструментом у конкурентній боротьбі на ринку послуг.

Складність оцінки послуг готельно-ресторанних закладів (ГРЗ) багато $d$ чому викликана труднощами формалізації, узагальненням та аналізом критеріїв оцінки, а також визначенням методів їх вимірювання, тому для встановлення якісних параметрів послуг найчастіше застосовують кваліметричні методи.

Розробка елементів СУЯ служби Housekeeping необхідна для підвищення технічного рівня та якості послуг ГРЗ при подальшому скорочені витрат та економії матеріальних і трудових ресурсів. Впровадження СУЯ та стандартизація робіт служби Housekeeping $\epsilon$ актуальними, що дf’ pvjue максимально ефективно виконувати роботу кожному учаснику процесу та спростити контроль над якістю проведених робіт.

Аналіз останніх досліджень і публікацій. Питанням розробки СУЯ у ГРЗ присвячена велика кількість наукових праць, серед яких [1-8].

Метою статті $\epsilon$ розробка елементів СУЯ служби Housekeeping у готельному господарстві за одночасного підвищення технічного рівня якості послуг, скороченя витрат та економії матеріально-технічних ресурсів.

Викладення основних результатів дослідження. У готельному господарстві служба Housekeeping є однією з найважливіших у готелі, забезпечує прибирання, підтримку чистоти і формування асортиментного ряду предметних послуг номерного фонду та громадських приміщень, якісний стан аксесуарів. Служба Housekeeping поєднує в собі функції підрозділів, які раніше виконувались адміністративно-господарською службою, службою господарського забезпечення та обслуговування готелю, службою покоївок, службою готельного господарства, службою експлуатації номерного фонду, поповерховою службою.

Розробляння та впровадження СУя служби Housekeeping (відповідно до вимог [9-11]), передбачає сукупність організаційних структур, методик, процесів і ресурсів, необхідних для здійснення загального керівництва якістю служби Housekeeping. Процеси, необхідні для розробляння СУЯ, повинні охоплювати сфери, пов'язані з управлінською діяльністю, а також постачанням ресурсів.

На першому етапі приймається рішення про створення СУЯ, визначається політика у сфері якості, формується служба якості, встановлюються основні етапи, виконавці, строки розробки та впровадження. Проводяться підготовчі роботи зі створення організаційної структури СУЯ на основних етапах створення та розробка комплексу документації СУЯ. Організаційна структура управління службою Housekeeping ілюструється схемою (рис. 1), що описує основні зобов'язання керівників і виконавців організації, які забезпечують функціонування СУЯ. 
Розробка документації СУЯ служби Housekeeping передбачає наявність документації, необхідної для належного функціонування СУЯ, та забезпечення якості продукції й послуг (рис. 2). Найбільш характерними видами документів у сфері якості є стандарти, процедури, методики, інструкції, програми забезпечення якості, поточна документація.

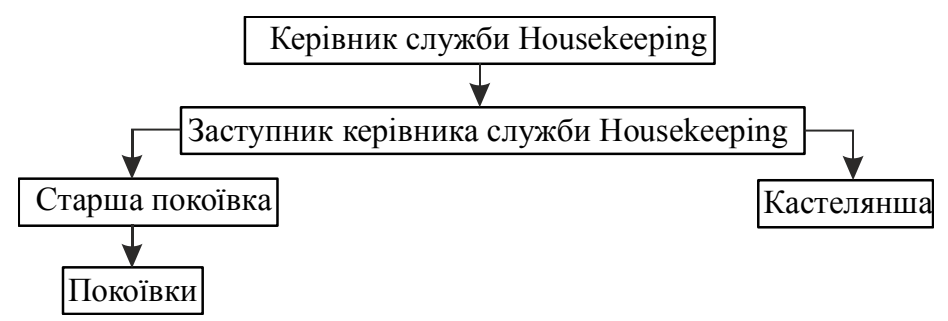

Рис. 1. Організаційна структура управління службою Housekeeping

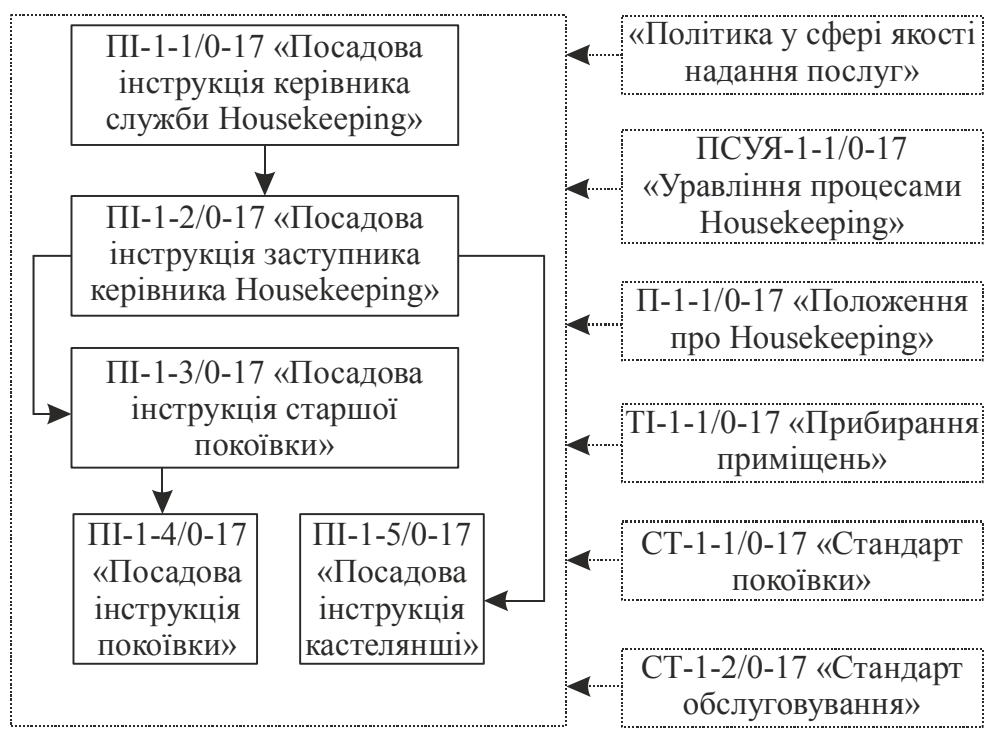

Рис. 2. Структура СУЯ служби Housekeeping

Обов'язки та повноваження персоналу службі Housekeeping, а отже, і відповідальність за виконання викладених обов'язків, відображені в положенні «Про Housekeeping» (П-1-1/0-17) та посадових інструкціях: «Посадова інструкція керівника служби Housekeeping» (Head Housekeeper) (ПI-1-1/0-17), при здійсненні загального керівництва виробничо-господарською діяльністю служби; «Посадова інструкція заступника керівника служби Housekeeping» (Assistant Housekeeper) (ПI-1-2/0-17), при здійсненні управлінських функцій служби; «Посадова інструкція старшої покоївки» (HSKP Supervisors) (ПI-1-3/0-17), при здійсненні господарської діяльності та управлінні покоївками; «Посадова інструкція покоївки» (Chambermaids) (ПI-1-4/0-17), при здійсненні господарської діяльності,в процесі прибирання номерів; «Посадова інструкція кастелянші» (Linen-Keeper) (ПІ-1-5/0-17). 
Відповідальність і повноваження співробітників при управлінні процесами СУЯ у службі Housekeeping розподілено згідно з матрицею (табл. 1).

Для перевірки рівня кваліфікації працівників використовується метод стандартів виконання, серед яких «Стандарт обслуговування» (СТ-1-2/0-17), що дає змогу оцінити досягнення співробітників рівня виконання своїх обов'язків, який вважається нормою для даного процесу. Розроблено «Стандарт покоївки» (СТ-1-1/0-17), який дає змогу оцінити відповідність дій працівників згідно з технологією збирання номерів (технологічна інструкція якості «Прибирання приміщень» TI-1-1/0-17. Для оцінки якості роботи працівників служби Housekeeping розроблені спеціальні нормативи, які контролює керівник служби та його заступник, що дає змогу проводити інвентаризацію, прописати об'єкти прибирання, вказати засоби, інструменти і методи прибирання, скласти технологічні карти щоденного та генерального прибирання.

Таблиця 1. Матриця розподілу відповідальності і повноважень

\begin{tabular}{|c|c|c|c|c|c|c|}
\hline Найменування операції & $\begin{array}{l}\text { Керівник } \\
\text { служби } \\
\text { House- } \\
\text { keeping }\end{array}$ & \begin{tabular}{|c|} 
Заступник \\
керівника \\
служби \\
House- \\
keeping
\end{tabular} & $\begin{array}{l}\text { Старша } \\
\text { покоївка }\end{array}$ & $\begin{array}{c}\text { По- } \\
\text { коївка }\end{array}$ & $\begin{array}{c}\text { Кас- } \\
\text { телян- } \\
\text { ша }\end{array}$ & $\begin{array}{l}\text { Голов- } \\
\text { ний } \\
\text { інженер }\end{array}$ \\
\hline Видача завдань на зміну & K & $\mathrm{K}, \mathrm{P}$ & B & B & B & \\
\hline $\begin{array}{c}\text { Дотримання вимог нормативної } \\
\text { документації при прийманні } \\
\text { прибраних номерів і видачі білизни }\end{array}$ & K & $\mathrm{K}, \mathrm{P}$ & K & B & & \\
\hline $\begin{array}{c}\text { Обслуговування, наладка та ремонт } \\
\text { обладнання }\end{array}$ & K & $\mathrm{C}$ & & & & $\mathrm{P}, \mathrm{B}$ \\
\hline Управління невідповідною послугою & K & $\mathrm{K}, \mathrm{P}$ & $\mathrm{B}$ & $\mathrm{B}$ & $\mathrm{B}$ & \\
\hline $\begin{array}{c}\text { Впровадження коригувальних і } \\
\text { запобіжних дій }\end{array}$ & K & $\mathrm{K}, \mathrm{P}$ & B & B & & $\mathrm{C}$ \\
\hline
\end{tabular}

*P — вирішує, К — контролює, В - виконує, С - співпрацює

Способи та методи прибирання постійно удосконалюються й розвиваються, але головним критерієм оцінки роботи покоївки залишаються бездоганна чистота номерів, іï охайність при виконанні прибиральних робіт, правильне i вміле поводження з прибиральними матеріалами та інвентарем.

Перед початком роботи покоївка отримує вказівку на черговість прибирання номерів. Спочатку забираються заброньовані номери та вільні номери, оскільки в них у будь-який час можуть поселити гостей. Якщо вони вже були прибрані у вечірній або нічний час, треба додатково протерти пил 3 полірованих поверхонь і перевірити якість прибирання санітарного вузла, наявність у ньому туалетного паперу, мила та іншого туалетного приладдя. Потім покоївка прибирає номери, які звільнилися після виїзду, щоб підготувати їх до заселення та не допустити простоїв. Лише після цього вона приступає до поточного щоденного прибирання номерів.

Окрім щоденної перевірки номера після прибирання покоївки (житлового та виїзного), вводиться графік «точкових перевірок», коли старша покоївка 
досконально перевіряє в день кілька номерів з розкриттям усього заправленого ліжка, щоб переконатися, що матрац, наматрацник, ковдри, подушки та ін., не мають плям, волосся і сторонніх запахів. При стандартній перевірці номера, без зняття постільної білизни, ці зони можуть бути просто невидимими.

Генеральне прибирання проводиться один раз у $7-10$ днів. Під час генерального прибирання видаляють пил із стін, прочищають вентиляційні грати, чистять пилососом драпіровки, пружинні матраци і перини, протирають стекла вікон і дверей. Генеральне прибирання проводиться, як правило, після натирання паркетних підлог у номері. При генеральному прибиранні номерів можуть проводитися також додаткові роботи (миття стін, килимів і килимових доріжок, фарбування підлог).

Для оптимізації методів роботи служби Housekeeping та відповідності сервісу світовим стандартам керівництво служби проводить професійні навчальні тренінги. Для цього розробляється план щомісячного навчання персоналу, яке $є$ обов'язковим для співробітників. За результатами кожного професійно-навчального тренінгу усі учасники навчання проходять тестування.

Основним документом СУЯ є настанова з якості — процедура СУЯ (ПСУЯ1-1/0-17 «Управління процесами Housekeeping»), яка встановлює порядок (послідовність) здійснення діяльності служби Housekeeping в структурі СУЯ, що відповідає вимогам ДСТУ ISO 9001:2015 [9] (табл. 2).

Роботи у службі Housekeeping вимагають чіткої координації дій з іншими підрозділами готелю: службою прийому і розміщення, інженерно-технічною службою, службою харчування, до якої входять ресторан, кухня, банкетна служба, рум-сервіс, службою безпеки, комерційним відділом, бухгалтерією та відділом інвентаризації.

Окрім цього, важливою складовою діяльності служби Housekeeping є внесок у збереження навколишнього середовища. Саме цій службі приходиться мати справу зі сміттям, усуненням забруднень, використанням реагентів, що завдають шкоду природі. Значний досвід накопичено у використанні програм, які обмежують використання технологій і реагентів, що впливають на природу.

\section{Таблиия 2. Структура процедури СУЯ}

\begin{tabular}{|c|c|c|c|}
\hline $\begin{array}{r}\text { № } \\
\text { П.П. }\end{array}$ & $\begin{array}{l}\text { Найменування } \\
\text { розділу }\end{array}$ & Зміст розділу & $\begin{array}{c}\text { Пп. ISO } \\
9001: 2015[9]\end{array}$ \\
\hline 1 & 2 & 3 & 4 \\
\hline 1 & Вступ & $\begin{array}{c}\text { Загальні відомості про організацію та іiі } \\
\text { продукцію; управління Настановами з якості }\end{array}$ & 4.2 .2 \\
\hline \multirow{3}{*}{2} & \multirow{3}{*}{$\begin{array}{c}\text { Загальні } \\
\text { положення }\end{array}$} & Принципи побудови й об’єкти управління & 4.1 \\
\hline & & Організаційна структура СУЯ & Розділ 5 \\
\hline & & $\begin{array}{c}\text { Відповідальність і повноваження керівництва. } \\
\text { Моніторинг СУя }\end{array}$ & Розділ 8 \\
\hline \multirow{3}{*}{3} & \multirow{3}{*}{ Процедури } & Структура документації СУЯ & 4.2 \\
\hline & & $\begin{array}{c}\text { Стислий опис або посилання на документовані } \\
\text { процедури СУя організації }\end{array}$ & Розділи 4,8 \\
\hline & & $\begin{array}{c}\text { Стандарти підприємства, програми та плани якості, } \\
\text { положення про підрозділи та посадові інструкції }\end{array}$ & Розділи 4-8 \\
\hline
\end{tabular}


Продовження табл. 2

\begin{tabular}{|c|c|c|c|}
\hline 1 & 2 & 3 & 4 \\
\hline 4 & Процеси & $\begin{array}{c}\text { Основні процеси СУЯ й їх взаємодія. Стислий опис } \\
\text { процесів у СУя або посилання на документи, що їх } \\
\text { визначають (процеси реалізації функцій вищого ке- } \\
\text { рівництва; управління ресурсами; життєвого циклу } \\
\text { продукції вимірювання, аналізу та поліпшення) }\end{array}$ & Розділи 5-8 \\
\hline 5 & $\begin{array}{c}\text { Нормативні } \\
\text { посилання }\end{array}$ & $\begin{array}{c}\text { Перелік і позначення документів, на які } є \\
\text { посилання в Настановах з якості }\end{array}$ & Розділ 2 \\
\hline 6 & $\begin{array}{c}\text { Визначення й } \\
\text { скорочення }\end{array}$ & Терміни, визначення й використані скорочення & Розділ 3 \\
\hline 7 & Зміни & Інформація про зміни Настанов з якості & \\
\hline
\end{tabular}

Велика кількість готелів розробили і реалізують програми із сортування та утилізації відходів (паперу, скла, металу, харчових відходів), скорочення використання паперової продукції в гостьових номерах (зі зростаючою популярністю Інтернет-технологій), застосування екологічно-безпечної продукції і технологій.

Для усвідомленої участі персоналу служби Housekeeping в цих заходах проводяться спеціальні навчання 3 метою залучення кожного співробітника до програми утилізації відходів.

\section{Висновки}

Отже, впровадження СУЯ у службі Housekeeping дає змогу постійно поліпшувати й оптимізувати роботу підрозділу, а також забезпечити умови для формування конкурентоспроможних послуг і підвищити їх ефективність. Здатність надавати послуги, які не лише задовольняють вимоги споживача, але й перевищують їх очікування — ось найголовніший показник конкурентоспроможності будь-якої організації.

\section{Література}

1. Екзархова Я.Д. Інновації на підприємствах готельного господарства / Я.Д. Екзархова, О.В. Кузьмін // Наукова творчість молоді в індустрії гостинності, матеріали 2 Всеукр. наук.-практ. конф. студ., аспірант., та молод. вчен. - Донецьк : ДонНУЕТ, $15 \varnothing ́ 16$ листопада 2012 р. - С. $270-271$.

2. Кількісна оцінка якості готельного продукту : монографія / В.Г. Топольник, А.П. Бутова, І.В. Кощавка, А.В. Полякова, О.В. Кузьмін, О.В. Куценко; ред.: В.Г. Топольник; Донец. нац. ун-т економіки і торгівлі ім. М. Туган-Барановського. - Донецьк : ДонНУЕТ, 2013. - 207 с.

3. Постоянкін I.C. Розробка елементів системи управління якістю у технологічному відділі готельно-ресторанного закладу / Постоянкін І.С., Кузьмін О.В. // Практика і перспективи розвитку еногастрономічного туризму: світовий досвід для України : Міжнародна науковопрактична конференція (24 вересня 2015 р.). — Київ : НУХТ, 2015. — С. 157-158.

4. Кузьмін O.B. Розробка системи управління якістю у готельних комплексах / О.В. Кузьмін, М.С. Черниш // Практика і перспективи розвитку еногастрономічного туризму: світовий досвід для України : Міжнародна науково-практична конференція (24 вересня 2015 р.). Київ : НУХТ, 2015. - С. 158-159.

5. Кузьмін O.В. Елементи системи управління якістю в готельно-ресторанних закладах на стадії виробництва продукції / О.В. Кузьмін, 3.В. Зваричук, Є.О. Єфімова // Якість і безпека харчових продуктів : II Міжнародна науково-практична конференція (12-13 листопада 2015 р.). — Київ : НУХТ, 2015. — С. 67-69. 
6. Сфімова С.О. Розробка та впровадження елементів системи управління якості послуг в службі прийому і розміщення / Є.О. Єфімова, К.В. Попович, О.В. Кузьмін // Проблеми управління і економіки підприємств в сучасних умовах : матеріали ХІІ Міжнарод. наук.практ. конф., присвяченої 85-річчю від дня народження д.е.н., проф. Чепурнова І.А., Київ, 26-27 травня 2016 р. : тези доп. — Київ : НУХТ, 2016. — С. 100-102.

7. Розвиток готельної індустрії в Україні / [Д.А. Макалендра, Д.Ю. Білоусов, О.В. Лівар, О.В. Кузьмін] // Наукові праці НУХТ, 2016. т. 22, № 4. - С. 61-75.

8. Попович К. Розробка системи управління якістю служби Housekeeping / К. Попович, О. Кузьмін // Матеріали 83 міжнародної наукової конференції молодих учених, аспірантів і студентів «Наукові здобутки молоді - вирішенню проблем харчування людства у ХХІ столітті», 5-6 квітня 2017 р. - Київ : НУХТ, 2017 р. - Ч. 3. - С. 268.

9. ДСТУ ISO 9001-2015. Системи управління якістю. Вимоги [Чинний від 2016-07-01]. Київ : УкрНДНЦ, 2016. - 31 с. - (Національний стандарт України).

10. ДСТУ ISO 9000:2007. Системи управління якістю. Основні положення та словник термінів [Чинний від 2008-01-01]. — Київ : Держспоживстандарт України, 2008. — 29 с. (Національний стандарт України).

11. ДСТУ 4268:2003. Послуги туристичні. Засоби розміщування. Загальні вимоги [Чинний від 2004-07-01]. - Київ : Держспоживстандарт України, 2004. - 9 с. - (Національний стандарт України). 